\title{
Migracje w regionie Trójmorza jako wyzwanie dla bezpieczeństwa spolecznego i ekonomicznego
}

$\mathrm{M}$ igracje to przemieszczanie się ludności w obrębie danego kraju lub pomiędzy różnymi państwami na określony czas lub pewien jego okres. Migracje mają wymiar przestrzenny. Na gruncie nauki, ale i praktyki stosunków międzynarodowych, nie wypracowano jednej uniwersalnej definicji migracji. Wielość terminów powoduje chaos i trudność w kompleksowym zdefiniowaniu tego zjawiska. Migracje mają znaczenie dla bezpieczeństwa państw w XXI wieku. Bezpieczeństwo jest pojęciem trudnym do jednoznacznego zdefiniowania ${ }^{163}$. W artykule zaproponowano powiązanie kwestii migracji z bezpieczeństwem społecznym i ekonomicznym. Zabieg ten ma na celu uporządkowanie prowadzonego wywodu. Problematyka migracji i możliwych implikacji dla bezpieczeństwa dotyczy właściwie wszystkich krajów na świecie. Aby, geograficznie ograniczyć pole badań zdecydowano się scharakteryzować państwa Inicjatywy Trójmorza ${ }^{164}$.

Migracje ludności są powiązane ze zmiennymi demograficznymi. Jest to konstatacja, która implikuje następujący wniosek: wymienione kategorie wzajemnie na siebie oddziałują. Zmienne demograficzne oraz migracje powinno się rozpatrywać wspólnie, gdyż tworzą kompleksowy obraz badanej rzeczywistości.

W eksploracji naukowej odwołano się do następujących metod:

163 „Przedmiotem poznania nauki o bezpieczeństwie powinna być działalność państwa, instytucji międzynarodowych oraz ogół zjawisk i stosunków związanych z zapewnieniem bezpieczeństwa w skali krajowej i globalnej. Można dodać, że zajmować się też powinna analizą zjawisk i procesów społecznych mających wpływ na poziom bezpieczeństwa i ich uwarunkowaniami i konsekwencjami. Obszar zainteresowania nauki o bezpieczeństwie jest bardzo szeroki, zróżnicowany i wielowarstwowy." Vide: A. Misiuk, O tożsamości nauk o bezpieczeństwie, Historia i Polityka Nr 23(30)/2018, s. 9-19.

${ }^{164}$ Inicjatywa Trójmorza jest elastyczną platformą polityczną na szczeblu prezydenckim, uruchomioną w $2015 \mathrm{r}$. Inicjatywa obejmuje 12 państw członkowskich UE położonych między Adriatykiem, Morzem Bałtyckim i Morzem Czarnym są to następujące kraje Austria, Bułgaria, Chorwacja, Czechy, Estonia, Węgry, Łotwa, Litwa, Polska, Rumunia, Słowacja i Słowenia. Vide: Inicjatywa Trójmorza: za: https: //three.si/ [dostęp: 11.04.2020]. 
- statystycznych ${ }^{165}$,szczególnie w analizie liczby ludności i wskaźnika przyrostu naturalnego;

- dedukcyjnych ${ }^{166}$, gdzie na bazie informacji dotyczących demografii formułowano wnioski dla problematyki dotyczącej migracji do państw regionu Trójmorza;

- odwołano się również do interdyscyplinarności, która pozwoliła w sposób holistyczny przeanalizować zachodzące zmiany i trendy w regionie.

$\mathrm{Na}$ tej podstawie sformułowano pytanie badawcze $\mathrm{w}$ brzmieniu: w jaki sposób migracje oddziałują na bezpieczeństwo społeczne i bezpieczeństwo ekonomiczne państw Trójmorza? Do pytania zaproponowano następującą hipotezę: migracje stanowią czynnik oddziałujący na bezpieczeństwo społeczne i ekonomiczne państw Trójmorza w następujący sposób: w wymiarze ekonomicznym, jako uzupełnienie potencjału ludnościowego, który ma na celu utrzymanie status quo i niedopuszczenie do załamania się systemu gospodarczego $\mathrm{w}$ państwach Inicjatywy; w wymiarze społecznym, jako problem o charakterze kulturowym spowodowany brakiem integracji, tym samym, jako zagrożenie dla stabilności i bezpieczeństwa państw w regionie.

Proces badawczy został podzielony na następujące etapy, które odpowiadają częściom prezentowanego opracowania:

- pierwszy, w którym, scharakteryzowano dane dotyczące populacji;

- drugi, w którym, odwołano się do oddziaływania migracji na bezpieczeństwo społeczne i ekonomiczne państw Trójmorza.

\section{Populacja i wskaźniki demograficzne dla regionu Trójmorza}

Prowadząc badania w sposób dedukcyjny, w pierwszej kolejności wskazano na liczbę ludności na świecie. Z danych statystycznych wynika, że wielkość populacji w roku 2019

\footnotetext{
165 „Bad ania polegają na wyciąganiu wniosków z wyodrębnionych cech zbiorów elementów statystycznych. Chodzi głównie o dwa rodzaje problemów wymagających analiz statystycznych. Problemu rozproszenia jednej zmiennej i problemu współzależności, czyli korelacji dwu lub więcej zmiennych. W obrębie pierwszego rodzaju problemów sprowadza się ją do poszukiwania średnich lub odchyleń w uporządkowanej liczbie spostrzeżeń z zakresu danej cechy zmiennej. Natomiast w obrębie drugiego rodzaju problemów prowadzone badania zmierzają do uzyskania współczynników korelacji, czyli współzależności dwóch lub większej liczby badań nad przyczynowymi zależnościami zjawisk (procesów)”. Vide: J. Apanowicz, Metodologia ogólna, Wydawnictwo Bernardinum, Gdynia 2002, s. 25.

${ }^{166}$ „Dedukcja (łac. deductio = wyprowadzenie), jako proces rozumowania polega na przechodzeniu od ogółu do szczegółu, czyli jest to taki proces myślowy, w którym na podstawie wiadomości o całości, wnioskujemy o niektórych częściach składowych (elementach, przedmiotach) z danej całość." Vide: Ibidem.
} 
wyniosła 7,7 miliarda ${ }^{167}$. Natomiast szacunkowa liczba ludności w roku 2050 wynosić będzie 9,9 miliarda ${ }^{168}$. Największy przyrost liczby ludności ma miejsce w państwach azjatyckich. Drugim, co do wielkości kontynentem z obserwowanym wzrostem populacji jest Afryka. Według raportu Funduszu Ludnościowego Narodów Zjednoczonych (United Nations Population Found - UNFPA) do 2050 roku liczba ludności w Afryce przekroczy 2 mld. W konsekwencji będzie to stanowiło $20 \%$ ludności świata w ogóle w połowie XXI wieku ${ }^{169}$. W przyszłości może to generować problemy dla państw rozwiniętych w postaci fal migrantów i uchodźców poszukujących dla siebie lepszych warunków życia ${ }^{170}$. Konstatacja ta jest zgodna $\mathrm{z}$ podstawową teorią dzielącą przyczyny migracji na dwie grupy czynników wypychających i przyciągających (push and pull factors) ${ }^{171}$.

Według danych populacja Europy będzie się zmniejszać: w 2019 roku wielkość populacji wynosiła: 745,5 miliona, w roku 2035 wynosić będzie 745,4 miliona, natomiast w roku 2050 będzie to 731,2 miliona $^{172}$. Stanowi wyzwanie dla utrzymania status quo w dziedzinie bezpieczeństwa państw. Biorąc pod uwagę region Trójmorza dane dotyczące populacji prezentują się w następujący sposób.

\footnotetext{
${ }^{167}$ Population Reference Bureau, za: https: //www.prb.org/international/geography/world, (9.04.2020).

${ }^{168}$ Ibidem.

${ }^{169} \mathrm{za}$ https://www.prb.org/2018-world-population-data-sheet-with-focus-on-changing-age-structures, $(10.04 .2020)$.

${ }^{170}$ Jak zauważył J. Stiglitz: „krytycy globalizacji wskazują na rosnącą liczbę mieszkańców świata żyjących w nędzy. W świecie odbywa się wyścig między wzrostem gospodarczym i wzrostem ludności i jak dotychczas wzrost ludności wygrywa" Vide: J. Stiglitz, Wizja sprawiedliwej globalizacji, PWN, Warszawa 2007, s. 29. W podobnym tonie utrzymane są badania J. Sachsa, który stwierdził: „młodzi ludzie, zwłaszcza ubodzy, bez stałego i pewnego zatrudnienia, są pożywką dla koszmarnych rojeń politycznych manipulatorów. Nie chodzi tu o to, aby obciążać najbiedniejsze kraje winą za ich fatalne położenie lub bać się ich. Obniżenie stopy dzietności ogółem, która w tych krajach ma tak wysoki poziom, przynajmniej w części pomoże zwiększyć ich bezpieczeństwo, a także nasze". Vide: J. Sachs, Nasze wspólne bogactwo. Ekonomia dla przeludnionej planety, Wydawnictwo Naukowe PWN, Warszawa 2009, s. 169.

${ }^{171}$ Pierwszą grupą są czynniki wypychające $\mathrm{z}$ miejsca zamieszkania (push factors): najczęściej jest to niekorzystna sytuacja ekonomiczna w kraju pochodzenia - bieda, bezrobocie lub niskopłatna praca, brak perspektyw życiowych - są to obecnie najczęściej występujące przyczyny wyjazdu. Powodem opuszczenia kraju są także niebezpieczne warunki życia takie jak: wojna, zamieszki, prześladowania czy klęski żywiołowe, ale mają one większe znaczenie dla migracji do Unii Europejskiej niż wewnątrz niej. Drugą grupą są czynniki przyciągające nowego miejsca (pull factors): rozwinięte i bogate kraje Europy Zachodniej są powszechnie kojarzone $\mathrm{z}$ dobrobytem i chłonnym rynkiem pracy z wyższym poziomem płac; wizja lepszych warunków egzystencji i poprawy sytuacji życiowej, (możliwość zdobywania wykształcenia i doświadczenia, łączenie rodzin) oraz bezpiecznego otoczenia (stabilność polityczna, rządy prawa, ochrona praw człowieka) skłania do decyzji o wyjeździe z ojczyzny.

${ }^{172}$ za: https://www.prb.org/international/geography/europe (8.04.2020).
} 
Tabela 1. Populacja w regionie Trójmorza dane i prognozy na 2019, 2035 i 2050 rok.

\begin{tabular}{|l|l|l|l|l|}
\hline \multicolumn{1}{|c|}{ Państwo } & \multicolumn{1}{c|}{ Rok 2019 } & \multicolumn{1}{c|}{ Rok 2035 } & \multicolumn{1}{c|}{ Rok 2050 } & \multicolumn{1}{c|}{ Trend } \\
\hline Austria & 8,9 miliona & 9,4 milionów & 9,7 milionów & $+0,8$ miliona \\
\hline Bułgaria & 7 milionów & 6,3 miliona & 5,8 miliona & $-1,2$ miliona \\
\hline Chorwacja & 4,1 miliona & 3,8 miliona & 3,4 miliona & $-0,7$ miliona \\
\hline Czechy & 10,7 milionów & 10,7 milionów & 10,6 miliona & $-0,1$ miliona \\
\hline Estonia & 1,3 miliona & 1,3 miliona & 1,3 miliona & 0,0 miliona \\
\hline Litwa & 2,8 miliona & 2,4 miliona & 2,2 miliona & $-0,6$ miliona \\
\hline Łotwa & 1,9 miliona & 1,6 miliona & 1,5 miliona & $-0,4$ miliona \\
\hline Polska & 38,4 miliona & 36,5 miliona & 34 miliona & $-4,4$ miliona \\
\hline Rumunia & 19,4 miliona & 17,2 miliony & 15,1 miliona & $-4,3$ miliona \\
\hline Słowacja & 5,5 miliona & 5,3 miliona & 5,0 milionów & $-0,5$ miliona \\
\hline Słowenia & 2,1 miliona & 2,0 miliona & 1,9 miliona & $-0,2$ miliona \\
\hline Węgry & 9,8 miliona & 9,4 miliona & 9 miliona & $-0,8$ miliona \\
\hline
\end{tabular}

Źródło: opracowanie własne na podstawie: https://www.prb.org/international (09.04.2020).

Na podstawie danych zgromadzonych w tabeli można skonstatować, że w regionie Trójmorza odnotowuje spadek liczby ludności w perspektywie 2050 roku. Jedynie w Austrii odnotowuje się przyrost populacji w perspektywie 2050 roku. Jest to konsekwencja masowego napływu migrantów. Powyższe dane stanowią podstawę do sformułowania następujących wniosków:

- państwa regionu Trójmorza w perspektywie roku 2035 jak i 2050 odnotowują spadek liczby ludności - stanowi to wyzwanie dla utrzymania obecnej struktury rynku pracy i uwarunkowań ekonomicznych związanych z wypłacaniem świadczeń socjalnych;

- dla rozwoju gospodarki napływ migrantów mógłby przyczynić się do wzrostu PKB i innych parametrów ekonomicznych. $Z$ punktu widzenia bezpieczeństwa społecznego istotnym problemem jest integracja kulturowa oraz przychylność społeczeństwa dla przyjmowania migrantów.

W analizowanym obszarze użyteczne będą też dane dotyczące przyrostu naturalnego w państwach Trójmorza. Pozwoli to dokonać pełniejszej analizy sytuacji demograficznej. Dane w znajdują się zamieszczonej tabeli. 
Tabela 2. Wskaźnik przyrostu naturalnego w państwach Trójmorza dane za rok 2018.

\begin{tabular}{|l|l|l|l|}
\hline \multicolumn{1}{|c|}{ Państwo } & \multicolumn{1}{|c|}{$\begin{array}{c}\text { Liczba urodzeń na 1000 } \\
\text { mieszkańców }\end{array}$} & $\begin{array}{c}\text { Liczba zgonów na 1000 } \\
\text { mieszkańców }\end{array}$ & $\begin{array}{c}\text { Wskaźnik przyrostu } \\
\text { naturalnego }\end{array}$ \\
\hline Austria & 10 & 9 & $0,0 \%$ \\
\hline Bułgaria & 9 & 15 & $-0,7 \%$ \\
\hline Chorwacja & 9 & 13 & $-0,4 \%$ \\
\hline Czechy & 11 & 11 & $0,0 \%$ \\
\hline Estonia & 11 & 12 & $-0,1 \%$ \\
\hline Litwa & 10 & 14 & $-0,4 \%$ \\
\hline Lotwa & 10 & 15 & $-0,5 \%$ \\
\hline Polska & 10 & 11 & $-0,1 \%$ \\
\hline Rumunia & 9 & 12 & $-0,3 \%$ \\
\hline Słowacja & 11 & 10 & $+0,1 \%$ \\
\hline Słowenia & 10 & 10 & $0,0 \%$ \\
\hline Węgry & 9 & 13 & $-0,4 \%$ \\
\hline
\end{tabular}

Źródło: opracowanie własne na podstawie: https://www.prb.org/international (09.04.2020).

Biorąc pod uwagę powyższe dane, może sformułować następujące wnioski:

- wskaźnik przyrostu naturalnego w państwach Inicjatywy jest w większości ujemny. W praktyce oznacza to, że w przyszłości w regionie sytuacja demograficzna może generować negatywne konsekwencje dla bezpieczeństwa społecznego oraz ekonomicznego;

- ujemny przyrost naturalny jest charakterystyczny dla państw, których społeczeństwa określane są, jako „starzejące się"173 oznacza to, że większość populacji jest w wieku produkcyjnym lub poprodukcyjnym.

Do negatywnych konsekwencji niskiego przyrostu naturalnego można zaliczyć: starzenie się społeczeństwa i wzrost liczby osób w wieku poprodukcyjnym. Wartościowe poznawczo, szczególnie w kontekście bezpieczeństwa ekonomicznego, jest wyeksponowanie wskaźnika obciążenia demograficznego. Jest to ludność w wieku nieprodukcyjnym przypadająca na ogół osób w wieku produkcyjnym. Wskaźnik obciążenia demograficznego odnosi liczbę dzieci (0-14 lat) i osób starszych (65 lat lub starszych) do populacji w wieku produkcyjnym (15-64 lata).W regionie Trójmorza wskaźnik ten przedstawia się w następujący sposób.

\footnotetext{
${ }^{173}$ Zjawisko to charakteryzuje się rosnącą liczbą ludności w wieku emerytalnym oraz kurczeniem się odsetka ludzi młodych (zwłaszcza dzieci i młodzieży), F. Stokowski, Demografia, Polskie Wydawnictwo Ekonomiczne, Warszawa 2015, s. 53.
} 
Tabela 3. Wskaźnik obciążenia demograficznego za rok 2018 wyrażone w procentach $(\%)$

\begin{tabular}{|l|l|}
\hline \multicolumn{1}{|c|}{ Państwo } & $\begin{array}{c}\text { Wskaźnik obciążenia } \\
\text { demograficznego za } \\
\text { rok 2018 }\end{array}$ \\
\hline Austria & 50 \\
\hline Bułgaria & 55 \\
\hline Chorwacja & 54 \\
\hline Czechy & 54 \\
\hline Estonia & 56 \\
\hline Litwa & 53 \\
\hline Łotwa & 56 \\
\hline Polska & 46 \\
\hline Rumunia & 51 \\
\hline Słowacja & 45 \\
\hline Słowenia & 53 \\
\hline Węgry & 51 \\
\hline
\end{tabular}

Źródło: opracowano na podstawie: Age dependency ratio (\% of working-age population), https://data.worldbank.org/indicator/SP.POP.DPND (10.04.2020).

Dla Inicjatywy Trójmorza wskaźnik obciążenia demograficznego w większości państw wynosi około $50 \%$ populacji. Biorąc pod uwagę dane dotyczące przyrostu naturalnego (ujemnego) i konstatacji o starzejącym się społeczeństwie, można przypuszczać, że w przyszłości wskaźnik ten będzie wzrastał. Może to przekładać się na niekorzystną sytuację w kontekście zapewnienia bezpieczeństwa ekonomicznego i utrzymania systemu świadczeń społecznych.

\section{Migracje w regionie Trójmorza}

W państwach należących do inicjatywy Trójmorza badania dotyczące migracji prowadzone są przez narodowe ośrodki statystyczne (odpowiedniki polskiego GUS). Badania te koncentrują się na różnych aspektach migracji, ponadto dane przedstawiane na stronach internetowych ośrodków statystycznych dotyczą różnych okresów - niekiedy jest to perspektywa wieloletnia, czasami ostatni rok/dwa. Wobec takiej różnorodności danych nie sposób na ich podstawie wyprowadzić wnioski dla całego Trójmorza. Tym samym dane te zostały przytoczone $\mathrm{w}$ ramach identyfikowania zjawiska migracji w poszczególnych państwach regionu, a nie całości Inicjatywy. 
Różnorodność danych jest czynnikiem prowadzącym do następującego uogólnienia, jeśli elity polityczne państw tworzących inicjatywę Trójmorza przyjmą założenie, zgodnie z którym migracje zostaną uznane za problem ważny i aktualny dla całej Inicjatywy, konsekwencją tego powinno być wprowadzenie w narodowych ośrodkach statystycznych jednolitych kryteriów badania migracji i publikowania danych.

Podejście to ułatwiłoby identyfikację tego zjawiska oraz określanie trendów na poziomie całej inicjatywy Trójmorza, jak również umożliwiałoby wypracowywanie wspólnych, międzyrządowych działań.

\section{Austria}

W tabeli przedstawiono dane dotyczące liczby imigrantów i emigrantów w Austrii w latach 2008-2018:

Tabela 4. Imigranci i emigranci w Austrii

\begin{tabular}{|l|l|l|}
\hline \multicolumn{1}{|c|}{ Rok/rodzaj migracji } & \multicolumn{1}{|c|}{ Imigranci } & \multicolumn{1}{c|}{ Emigranci } \\
\hline 2008 & 109713 & 85063 \\
\hline 2009 & 107523 & 90470 \\
\hline 2010 & 112691 & 91375 \\
\hline 2011 & 124619 & 93914 \\
\hline 2012 & 140358 & 96561 \\
\hline 2013 & 151280 & 96552 \\
\hline 2014 & 170115 & 97791 \\
\hline 2015 & 214410 & 101343 \\
\hline 2016 & 174310 & 109634 \\
\hline 2017 & 154749 & 110119 \\
\hline 2018 & 146856 & 111555 \\
\hline
\end{tabular}

Źródło: Migration overview, Statistics Austria, http://www.statistik.at/web_en/statistics/PeopleSociety/populatio $\mathrm{n} /$ migration/migration_total/index.html (4.04.2020).

$\mathrm{Na}$ podstawie danych przedstawionych $\mathrm{w}$ tabeli można zauważyć, że w badanym okresie szczytowym momentem $\mathrm{w}$ zakresie imigracji był rok 2015, zatem moment wzmożonego napływu do Europy uchodźców oraz migrantów zarobkowych $\mathrm{z}$ regionu MENA. Po 2015 r. liczba migrantów stopniowo malała, pozostając jednak na poziomie wyższym niż przed 2013 r. W przypadku emigracji kluczowym jest również 2015 r., wówczas to ogólna liczba emigrantów pierwszy raz w badanym okresie przekroczyła 100000 . Od tamtego roku dane dotyczące emigracji oscylują w okolicach 110000.

\section{Bulgaria}

W 2018 r. Bułgaria przyjęła 29559 imigrantów, przede wszystkim z Turcji (29,9\%), Rosji (11\%) i Niemiec (7,2\%). Kobiety stanowiły 50,7\% a mężczyźni 49,3\% ogólnej ilości imigrantów. Struktura wiekowa imigrantów w 2018 r. przedstawiała się następująco: 
- poniżej 20 lat: 19\%;

- 20-39 lat: $35,5 \%$;

- 40-59 lat: $27,6 \%$;

- powyżej 60 lat: $17,9 \%$.

W 2018 r. Bułgarię opuściło 33225 osób, osoby te kierowały się przede wszystkim do Niemiec (24,4\%), Wielkiej Brytanii (17,8\%) i Włoch (7,5\%). Kobiety stanowiły 48,6\% a mężczyźni 51,4\% ogólnej liczby emigrantów. Struktura wiekowa emigrantów w 2018 r. przedstawiała się następująco:

- poniżej 20 lat: $15,8 \%$;

- 20-39 lat: 49,4\%;

- 40-59 lat: 25,6;

- powyżej 60 lat: $9,2 \%{ }^{174}$.

\section{Chorwacja}

W tabeli przedstawiono dane dotyczące liczby imigrantów i emigrantów w Chorwacji w latach 2013-2017:

Tabela 5. Imigranci i emigranci w Chorwacji.

\begin{tabular}{|l|l|l|}
\hline \multicolumn{1}{|c|}{ Rok/rodzaj migracji } & \multicolumn{1}{|c|}{ Imigranci } & \multicolumn{1}{c|}{ Emigranci } \\
\hline 2013 & 10738 & 15262 \\
\hline 2014 & 10638 & 20858 \\
\hline 2015 & 11706 & 29651 \\
\hline 2016 & 13985 & 36436 \\
\hline 2017 & 15553 & 47352 \\
\hline
\end{tabular}

Źródło: Statistical Yearbook of the Republic of Croatia, Croatian Bureau of Statistic, Zagreb 2018, https://www.dzs.hr/Hrv_Eng/ljetopis/2018/sljh2018.pdf, s. 25. (4.04.2020).

Z danych przytoczonych $\mathrm{w}$ powyższej tabeli wynika, że zarówno liczba imigrantów (za wyjątkiem 2014 r.), jak i emigrantów rośnie. W tej grupie jest to wzrost znacznie bardziej dynamiczny, czego egzemplifikacją jest różnica między liczbą imigrantów a emigrantów. Druga z tych grup przeważała nad pierwszą w 2013 r. o niecałe 50\%, w 2017 r. była to już około trzykrotna przewaga.

\section{Czechy}

W 2017 r. Czechy opuściło 17684 emigrantów (w tym 3256 mających czeskie obywatelstwo), rok później 19519 emigrantów (w tym 3271 mających czeskie 174 Population and demographic processes 2018, National statistical institute, Sofia 2019, https:/www.nsi.bg/sites/default/files/files/publications/DMGR2018.pdf, s. 32-33 [dostęp: 3.11.2019]. 
obywatelstwo). W 2017 r. do Czech przybyło 45957 imigrantów, rok później było to 58148 osób $^{175}$.

Czech Statistical Office publikuje również dane dotyczące liczby obcokrajowców (w zależności od typu pobytu) oraz liczby nielegalnych migracji (w zakresie przekroczenia granicy oraz nielegalnego pobytu). Obydwie grupy danych prezentowane są w wieloletnich perspektywach.

Tabela 6. Dane dotyczące liczby obcokrajowców według typu pobytu w Czechach.

\begin{tabular}{|l|l|l|l|}
\hline \multicolumn{1}{|c|}{ Rok/typ pobytu } & \multicolumn{1}{|c|}{ Pobyt stały } & \multicolumn{1}{c|}{$\begin{array}{c}\text { Pobyt } \\
\text { długoterminowy } \\
\text { (powyżej 90 dni) }\end{array}$} & \\
\hline 2004 & 99000 & 155000 & 254000 \\
\hline 2005 & 111000 & 168000 & 278000 \\
\hline 2006 & 139000 & 182000 & 321000 \\
\hline 2007 & 158000 & 235000 & 392000 \\
\hline 2008 & 172000 & 265000 & 438000 \\
\hline 2009 & 180000 & 252000 & 433000 \\
\hline 2010 & 189000 & 235000 & 424000 \\
\hline 2011 & 196000 & 238000 & 434000 \\
\hline 2012 & 212000 & 223000 & 436000 \\
\hline 2013 & 237000 & 203000 & 439000 \\
\hline 2014 & 250000 & 200000 & 449000 \\
\hline 2015 & 260000 & 205000 & 465000 \\
\hline 2016 & 272000 & 221000 & 493000 \\
\hline 2017 & 281000 & 243000 & 524000 \\
\hline 2018 & 289000 & 275000 & 564000 \\
\hline
\end{tabular}

Źródło: Foreigners: Number of foreigners, Czech Statistical Office, za://www.czso.cz/csu/cizinci/1ciz_pocet_cizincu (4.04.2020).

$\mathrm{Z}$ danych przedstawionych $\mathrm{w}$ powyższej tabeli wynika, że łączna liczba cudzoziemców przebywających w Czechach na stałe lub w ramach pobytu długoterminowego (powyżej 90 dni) w 2018 r. była ponad dwukrotnie wyższa niż w 2004 r. Między 2015 r. a 2018 r. liczba ta zrosła o 99 000. Można również zaobserwować, że do 2012 r. liczba cudzoziemców przebywających w Czechach w ramach pobytu długotrwałego była wyższa od tych, którzy przebywali w Czechach na stałe. Od 2013 r. ta druga zmienna osiąga większe wartości.

\footnotetext{
${ }^{175}$ Statistical Yearbook of the Czech Republic - 2019, Czech Statistical Office, https://www.czso.cz/csu/czso/4population-1 gohqz7tfv [dostęp: 3.11.2019].
} 


\section{Estonia}

W tabeli przedstawiono dane dotyczące liczby imigrantów i emigrantów w Estonii w latach 2009-2018:

Tabela 7. Imigranci i emigranci w Estonii.

\begin{tabular}{|l|l|l|}
\hline \multicolumn{1}{|c|}{ Rok/rodzaj migracji } & \multicolumn{1}{c|}{ Imigranci } & \multicolumn{1}{c|}{ Emigranci } \\
\hline 2009 & $3884 \quad$ & 4658 \\
\hline 2010 & 2810 & 5294 \\
\hline 2011 & 3709 & 6214 \\
\hline 2012 & 2639 & 6321 \\
\hline 2013 & 4098 & 6740 \\
\hline 2014 & 3904 & 4637 \\
\hline 2015 & 15413 & 13003 \\
\hline 2016 & 14822 & 13792 \\
\hline 2017 & 17616 & 12358 \\
\hline 2018 & 17547 & 10476 \\
\hline
\end{tabular}

Źródło: External migration, years, Statistic Estonia, za: https://www.stat.ee/34286 (4.04.2020).

$\mathrm{Z}$ danych przedstawionych $\mathrm{w}$ powyższej tabeli wynikają dwa główne wnioski. Po pierwsze, od 2015 r. liczba imigrantów i emigrantów jest znacząco wyższa od wielkości migracji w latach poprzednich. Po drugie, również w 2015 r. nastąpiło odwrócenie dotychczasowego trendu, w efekcie liczba imigrantów jest większa od liczby emigrantów. Ten drugi volumen po 2016 r. zaczyna maleć, niemniej ciągle jest znacząco większy od danych notowanych przed $2015 \mathrm{r}$.

\section{Litwa}

W tabeli przedstawiono dane dotyczące liczby imigrantów i emigrantów na Litwie w latach 2014-2018:

Tabela 8. Imigranci i emigranci na Litwie.

\begin{tabular}{|l|l|l|}
\hline \multicolumn{1}{|c|}{ Rok/rodzaj migracji } & \multicolumn{1}{c|}{ Imigranci } & \multicolumn{1}{c|}{ Emigranci } \\
\hline 2014 & $24294 \quad$ & 36621 \\
\hline 2015 & 22130 & 44553 \\
\hline 2016 & 20162 & 50333 \\
\hline 2017 & 20368 & 47925 \\
\hline 2018 & 28914 & 32206 \\
\hline
\end{tabular}

Źródło: Official Statistic Portal, za: https://osp.stat.gov.lt/statistiniu-rodikliu-analize?theme=all\#/ (4.04.2020).

$\mathrm{Z}$ danych przedstawionych $\mathrm{w}$ tabeli wynika, że emigrantów jest więcej niż imigrantów, jakkolwiek różnice $\mathrm{w}$ tym zakresie potrafią być znaczne. W 2016 r. różnica ta wynosiła ponad 30 000, w 2018 r. różnica ta wyniosła mniej niż 3 500. Stało się tak za sprawą 
znacznego zwiększenia liczby imigrantów (ponad 8000 w porównaniu z rokiem poprzednim) oraz jeszcze większego spadku liczby emigrantów (ponad $15000 \mathrm{w}$ porównaniu z rokiem poprzednim).

W 2018 r. obcokrajowcy przybywający na Litwę imigrowali przede wszystkim z Ukrainy (5 737), Białorusi (3 256) i Rosji (783). W tym samym roku Litwini powracający z emigracji wracali głównie z Wielkiej Brytanii (7 596), Norwegii (1 875), Irlandii (1 231) oraz Niemiec (1 212). Również te cztery państwa były celem emigrantów z Litwy w 2018 r., dane w tym zakresie są następujące: Wielka Brytania (12 157), Niemcy (3 169), Norwegia (3 000), Irlandia (2 014). Co warte podkreślenia, wielkość emigracji w 2017 r. była znacznie większa, osiągając wymiar 21577 osób. W tym samym roku do Norwegii wyjechało 5031 osób, do Niemiec 4136 osób, a do Irlandii 3355 osób ${ }^{176}$.

\section{Lotwa}

W tabeli przedstawiono dane dotyczące liczby imigrantów i emigrantów na Łotwie w latach 2010-2018 ${ }^{177}$ :

Tabela 9. Imigranci i emigranci na Lotwie.

\begin{tabular}{|l|l|l|}
\hline \multicolumn{1}{|c|}{ Rok } & \multicolumn{1}{|c|}{ Imigranci } & \multicolumn{1}{c|}{ Emigranci } \\
\hline 2010 & 4011 & 39651 \\
\hline 2011 & 10234 & 30311 \\
\hline 2012 & 13303 & 25163 \\
\hline 2013 & 8299 & 22561 \\
\hline 2014 & 10365 & 19017 \\
\hline 2015 & 9479 & 20119 \\
\hline 2016 & 8345 & 20574 \\
\hline 2017 & 9916 & 17724 \\
\hline 2018 & 10909 & 15814 \\
\hline
\end{tabular}

Źródło: Central Statistical Bureau of Latvia, za: https://data1.csb.gov.lv/pxweb/en/iedz/iedz_migr/IBG010.px/ (4.04.2020).

$\mathrm{Z}$ danych przedstawionych $\mathrm{w}$ powyższej tabeli wynika, że liczba emigrantów przeważa nad liczbą imigrantów. Różnica w tym zakresie w ostatnim badanym roku jest znacznie mniejsza (niecałe 5000 ) niż w poprzednich latach, kiedy to emigrantów było zwykle około dwa razy więcej niż imigrantów - jakkolwiek zdarzały się w tym zakresie różnice znacznie większe (lata 2010, 2011, 2013).

\footnotetext{
${ }^{176}$ Statistical yearbook of Lithuania (edition 2019), Official Statistic Portal, za: https://osp.stat.gov.lt/lietuvosstatistikos-metrastis/lsm-2019/gyventojai-ir-socialine-statistika/nuolatiniai-gyventojai (4.11.2019).

${ }^{177}$ Central Statistical Bureau of Latvia umożliwia zapoznanie się z danymi sięgającymi 1951, na potrzeby niniejszego opracowania wybrano lata 2010-2018.
} 


\section{Polska}

W tabeli przedstawiono dane dotyczące liczby imigrantów i emigrantów w Polsce za lata 2010-2018, za wyjątkiem roku 2015 (brak danych za ten rok).

Tabela 10. Imigranci i emigranci w Polsce.

\begin{tabular}{|l|l|l|}
\hline \multicolumn{1}{|c|}{ Rok } & \multicolumn{1}{|c|}{ Imigranci } & \multicolumn{1}{c|}{ Emigranci } \\
\hline 2010 & 15200 & 17400 \\
\hline 2011 & 15500 & 19900 \\
\hline 2012 & 14600 & 12200 \\
\hline 2013 & 12300 & 28100 \\
\hline 2014 & 13500 & 12000 \\
\hline 2015 & $\mathrm{X}$ & $\mathrm{X}$ \\
\hline 2016 & 13500 & 12000 \\
\hline 2017 & 13300 & 11900 \\
\hline 2018 & 15500 & 11800 \\
\hline
\end{tabular}

Źródło: Ludność. Stan i struktura oraz ruch naturalny w przekroju terytorialnym $w 2018$ r. Stan $w$ dniu 31 XII, Główny Urząd Statystyczny, za: https://stat.gov.pl/obszary-tematyczne/ludnosc/ludnosc/ludnosc-stan-i-strukturaoraz-ruch-naturalny-w-przekroju-terytorialnym-w-2018-r-stan-w-dniu-31-xii,6,25.html (10.04.2020).

Zgodnie z danymi PESEL (Powszechny Elektroniczny System Ewidencji Ludności) wynika, że saldo migracji zagranicznych na pobyt stały osiągnęło w 2018 r. wartość $+3,6$ tys. osób, co oznacza, że liczba emigracji była mniejsza od liczby imigracji. Jest to interesująca obserwacja ponieważ tradycyjnie Polska jest uznawana za kraj emigracyjny.

\section{Rumunia:}

W 2018 r. do Rumunii przybyło 181344 imigrantów, w tym 97979 mężczyzn, 83365 kobiet. Najliczniejsze w tym zakresie były następujące grupy wiekowe:

- 25-29: 23600 osób, w tym 12621 mężczyzn, 10979 kobiet;

- 30-34: 27351 osób, w tym 15110 mężczyzn, 12241 kobiet;

- 35-39: 25205 osób, w tym 15153 mężczyzn, 10052 kobiet;

- 40-44: 20084 osób, w tym 12323 mężczyzn, 7761 kobiet.

W tym samym roku z Rumunii wyemigrowało 238926 osób, w tym 142311 mężczyzn, 96615 kobiet. Najliczniejsze w tym zakresie były następujące grupy wiekowe:

- 20-24: 34271 osób, w tym 21237 mężczyzn, 13034 kobiet;

- 25-29: 37921 osób, w tym 24334 mężczyzn, 13587 kobiet;

- 30-34: 29912 osób, w tym 20042 mężczyzn, 9870 kobiet; 
- 35-39: 22454 osób, w tym 15354 mężczyzn, 7100 kobiet;

- 40-44: 19950 osób, w tym 12360 mężczyzn, 7545 kobiet $^{178}$.

Z powyższych danych wynika większa skłonność mężczyzn do migracji - w przypadku imigracji im późniejszy wiek, tym różnica między liczbą mężczyzn a kobiet jest większa, w przypadku emigracji tendencja jest odwrotna. W przypadku zarówno imigracji, jak i emigracji można również zauważyć, że jest to przede wszystkim domena ludzi młodych oraz będących w średnim wieku.

\section{Słowacja}

W 2018 r. na Słowacji przybyło 7253 imigrantów, głównie z Czech (23,9\%), Wielkiej Brytanii (13,8\%), Austrii (8\%) i Niemiec (6,7\%). W tym samym roku ze Słowacji emigrowało 3298 osób, kierując się przede wszystkim do Czech (35,5\%), Austrii (22,5\%), Wielkiej Brytanii (9\%) i Niemiec $(8,9 \%)^{179}$.

W kontekście powyższych danych szczególną uwagę zwraca pierwsze miejsce Czech, zarówno w zakresie imigracji, jak i emigracji. Można zakładać, że jest to spowodowane wyjątkową bliskością obydwu społeczeństw, wynikającą ze wspólnej historii, co przekłada się m.in. na kwestię związków rodzinnych między Słowakami a Czechami.

\section{Słowenia}

W tabeli przedstawiono dane dotyczące liczby imigrantów i emigrantów na Słowenii w latach 2017-2018:

Tabela 11. Imigranci i emigranci w Słowenii.

\begin{tabular}{|l|l|l|}
\hline \multicolumn{1}{|c|}{ Rodzaj migracji/rok } & $\mathbf{2 0 1 7}$ & \multicolumn{2}{c|}{$\mathbf{2 0 1 8}$} \\
\hline Imigranci łącznie & 18808 & 28455 \\
\hline Imigranci - obywatele Słowacji & 3288 & 4354 \\
\hline Imigranci - obcokrajowcy & 15520 & 24101 \\
\hline Emigranci łącznie & 17555 & 13527 \\
\hline Emigranci - obywatele Słowacji & 9871 & 6595 \\
\hline Emigranci - obcokrajowcy & 7684 & 6932 \\
\hline
\end{tabular}

Źródło: Migration changes, Slovenia, 2018, Republic of Slovenia Statistical Office, za: https://www.stat.si/StatWeb/en/News/Index/8217 (4.11.2019).

\footnotetext{
178 Press release no 212/29.08.2019, National Institute of Statistics, za: http://www.insse.ro/cms/sites/default/files/com_presa/com_pdf/poprez_ian2019e.pdf (4.04.2020).

179 Slovak Republic in Figures 2019, Statistical Office of the Slovak Republic, za: https://slovak.statistics.sk/, s. 24, (4.11.2019).
} 
Z danych przedstawionych w powyższej tabeli wynika, że w 2018 r. znacząco zwiększyła się liczba imigrantów nad liczbą emigrantów. Przyczynił się do tego zarówno spadek liczby emigrantów jak i znaczący wzrost imigrantów obcokrajowców. W 2017 r. imigranci będący obywatelami Słowacji przyjeżdżali przede wszystkim z Niemiec (23\%) i Austrii (17\%). Imigranci obcokrajowcy przybywali na Słowację głównie $z$ Bośni i Hercegowiny $(40 \%)^{180}$.

\section{Węgry}

W tabeli przedstawiono dane dotyczące liczby imigrantów i emigrantów na Węgrzech w latach 2010-2018:

Tabela 12. Imigranci i emigranci na Węgrzech.

\begin{tabular}{|l|l|l|}
\hline \multicolumn{1}{|c|}{ Rok/rodzaj migracji } & \multicolumn{1}{|c|}{ Imigranci } & \multicolumn{1}{c|}{ Emigranci } \\
\hline 2010 & 1635 & 7318 \\
\hline 2011 & 5504 & 12413 \\
\hline 2012 & 13362 & 12964 \\
\hline 2013 & 17718 & 21580 \\
\hline 2014 & 28577 & 31385 \\
\hline 2015 & 32557 & 32852 \\
\hline 2016 & 29815 & 29425 \\
\hline 2017 & 31617 & 26957 \\
\hline 2018 & 33625 & 23808 \\
\hline
\end{tabular}

Źródło: Hungarian Central Statistical Office, za:

http://www.ksh.hu/docs/eng/xstadat/xstadat_annual/i_wnvn004.html (4.04.2020).

$\mathrm{Z}$ danych przedstawionych $\mathrm{w}$ powyższej tabeli wynika, że $\mathrm{w}$ porównaniu do początków badanego okresu znacząco zwiększyła się liczba zarówno imigrantów, jak i emigrantów. Pod względem różnic między tymi dwoma grupami, w początkowym okresie emigranci zdecydowanie przeważali, od 2012 r. trudno w tym zakresie zdefiniować jakikolwiek trend.

Reasumując dane przedstawione powyżej w zamieszonej tabeli wskazano na saldo migracji w krajach Trójmorza. Saldo migracji liczy się w następujący sposób: liczba imigrantów minus liczba emigrantów. Jest to wskaźnik, który pozwala w pełni przeanalizować sytuację dotyczącą migracji w regionie Trójmorza.

Tabela 13. Saldo migracji w państwach Trójmorza.

\begin{tabular}{l|l|l|l|}
\hline Państwo & Liczba imigrantów & Liczba emigrantów & Saldo migracji \\
\hline $180 \quad$ National $\quad$ statistics in $2018, \quad$ Republic of $\quad$ Slovenia & Statistical & Office, \\
https://www.stat.si/StatWeb/File/DocSysFile/10615/LPSR-2018-ang.pdf, s. 15 [[dostęp: 4.04.2020].
\end{tabular}




\begin{tabular}{|l|l|l|l|}
\hline Austria & 146856 & 111555 & +35301 \\
\hline Bułgaria & 29559 & 33225 & -3666 \\
\hline Chorwacja & Brak danych & Brak danych & Brak danych \\
\hline Czechy & 58148 & 19519 & +38629 \\
\hline Estonia & 17547 & 10476 & +7071 \\
\hline Litwa & 28914 & 32206 & -3292 \\
\hline Łotwa & 10909 & 15814 & -4905 \\
\hline Polska & 15500 & 11800 & +3700 \\
\hline Rumunia & 181344 & 238926 & -57582 \\
\hline Słowacja & 7253 & 3298 & +3955 \\
\hline Słowenia & 28455 & 13527 & +14928 \\
\hline Węgry & 33625 & 23808 & +9817 \\
\hline
\end{tabular}

Źródło: opracowanie własne na podstawie danych statystycznych.

Biorąc pod uwagę badania przeprowadzone do artykułu państwa Inicjatywy Trójmorza można podzielić na trzy podgrupy:

- państwa, które nie są atrakcyjne dla potencjalnych imigrantów, do państw tych zaliczyć można: Bułgarię, Litwę, Łotwę i Rumunię;

- państwa, które są potencjalnie atrakcyjne dla imigrantów. Mogą również być punktem tranzytowym do dalszej eksploracji państw lepiej rozwiniętych gospodarczo. Do grupy tej zaliczyć można: Chorwację, Czechy, Estonię, Polskę, Słowację, Słowenię i Węgry;

- państwo, które jest atrakcyjne dla imigrantów i jako jedyne przystąpiło do Unii Europejskiej przed 2004 rokiem, jest to Austria.

Państwa Inicjatywy Trójmorza są bardzo niejednorodne w kontekście migracji. Państwa zaliczone do pierwszej grupy: Bułgaria, Litwa, Łotwa i Rumunia to kraje emigracji. Wszystkie wymienione państwa mają malejącą liczbę populacji do roku 2050, ujemny wskaźnik przyrostu naturalnego oraz ujemne saldo migracji. W Bułgarii dodatkowo problematyczne okazały się zapisy ustawy o obywatelstwie, zgodnie z którą każdy starający się o obywatelstwo musiał inwestować w kraju. Szybki dostęp do obywatelstwa (po 18-24 miesiącach pobytu, a nie po pięciu latach) pozostawał dostępny dla inwestorów, ale nowy wymóg został uzupełniony o osobistą rozmowę w języku bułgarskim. Ustawa ta została skrytykowana przez przedstawicieli Unii Europejskiej, następnie wniesiono projekt ustawy o zmianie bułgarskiej ustawy o obywatelstwie, która wyeliminowałaby obywatelstwo dzięki przepisom inwestycyjnym $^{181}$.

181 OECD (2018), International Migration Outlook 2018, OECD Publishing, Paris, za: https://doi.org/10.1787/migr_outlook-2018-en. (4.04.2020). 
Na Litwie ogłoszono strategię polityki demograficznej, migracji i integracji na lata 2018-2030. Strategia została przyjęta 20 września 2018 r. Dokument określa trzy cele związane z: tworzeniem środowiska przyjaznego rodzinie, zarządzaniem przepływami migracyjnymi oraz integracją seniorów z życiem publicznym. Strategia przewiduje zachęcanie do migracji powrotnej, a także zrównoważony przyjazd cudzoziemców poprzez politykę przyciągania, przyjmowania, integracji i pomocy ${ }^{182}$. Jest to działanie, które ma na celu zahamowanie niekorzystnego trendu dotyczącego większej liczby emigrantów niż imigrantów oraz ujemnego przyrostu naturalnego.

$\mathrm{Na}$ Łotwie zainicjowano projekt, w którym szczególną rolę odgrywają koordynatorzy ds. migracji. W ciągu pierwszych ośmiu miesięcy projektu koordynatorzy skontaktowali się z około 1300 łotewskimi rodzinami emigrantów, z których 10\% wróciło na Łotwę. Koordynatorzy informują łotewskich emigrantów o zmieniających się warunkach życia na Łotwie. W ramach tej inicjatywy powracający emigranci kwalifikują się również do wsparcia finansowego w wysokości do 9000 EUR na rozpoczęcie działalności gospodarczej.

Państwa wymienione powyżej reprezentują dwa podejścia do problematyki bezpieczeństwa ekonomicznego i społecznego. Działania proaktywne, które można odnotować na Litwie i Łotwie. W państwach tych wdrożono programy, które zachęcają do zwiększenia dzietności wśród obywateli a także wspomagają powrót emigrantów do kraju. Należy założyć, że są to działania długofalowe i w takiej perspektywie mogą przynieś pożądany rezultat. Drugie podejście do problematyki można nazwać biernym. Państwa takie jak Bułgaria i Rumunia nie wystarczająco angażują się $\mathrm{W}$ sprawy związane $\mathrm{z}$ bezpieczeństwem społecznym i ekonomicznym. Może to w przyszłości skutkować załamaniem się rynku i kryzysem gospodarczym.

Kolejną grupę państw stanową te, które są potencjalnie atrakcyjne dla imigrantów. Grupa ta jest również bardzo niejednorodna. Możemy do niej zaliczyć: Chorwację, Czechy, Estonię, Polskę, Słowację, Słowenię i Węgry. W większości państw wielkość populacji będzie się zmniejszać w perspektywie 2050 roku (oprócz Estonii, gdzie według danych zostanie utrzymana wielkość populacji z roku 2019). Dane dotyczące przyrostu naturalnego w większości państw są ujemne. W Czechach i Słowenii utrzymuje się na poziomie zero. Natomiast na Słowacji jest dodatni $(+0,1)$. Saldo migracji utrzymuje się na dodatnim poziomie. W większości państw, jest to konsekwencja otwarcia rynku na pracowników z Ukrainy. W Czechach w styczniu 2018 r. rząd podwoił roczny limit na zatrudnienie

${ }^{182}$ Ibidem 
wykwalifikowanych i średnio wykwalifikowanych migrantów z Ukrainy do 19600 osób rocznie. Wprowadzono również programy migracji dla pracowników z Mongolii (1 000 rocznie), Filipin (1 000 na rocznie), Serbii (2 000 pracowników rocznie) i wysoko wykwalifikowanych pracowników z Indii (500 rocznie). W Estonii w ramach inicjatywy Work in Estonia rząd przeznaczył dodatkowe środki na dotację rekrutacyjną na zatrudnienie zagranicznych specjalistów z dziedziny teleinformatycznej i komputerowej (ICT). W Polsce obserwuje się migracje cyrkulacyjne pracowników z Ukrainy. Jest to, zatem migracja typowo zarobkowa nienastawiona na osiedlanie się. Dodatkowo należy odnotować, że trwają prace nad strategią sektorową dotyczącą polskiej polityki migracyjnej ${ }^{183}$.

Należy stwierdzić, że państwa zaliczane do grupy potencjalnie atrakcyjnych dla imigrantów reprezentują proaktywne podejście, $\mathrm{w}$ kontekście zmian $\mathrm{w}$ obszarze bezpieczeństwa ekonomicznego i społecznego. Wybrane przykłady jednoznacznie potwierdzają, że działania rządowe mają na celu niedopuszczenie do sytuacji kryzysowej. Kwestią otwartą natomiast pozostają działania dotyczące integracji potencjalnych imigrantów ze społeczeństwem.

Państwo, które zaliczono do grupy atrakcyjnych dla imigrantów to Austria. Kojarzona jest z państwem dobrobytu i zaliczana do państw, „zachodnich”. Dlatego też można przewidywać, że nadal będzie celem dla imigrantów.

\section{Wnioski}

Cele dla projektu Trójmorza nie zostały jasno sprecyzowane. Najważniejszymi dokumentami w ramach celów deklarowanych są deklaracje z Dubrownika, Warszawy, Bukaresztu i Lubljany. W ramach funkcjonowania Inicjatywy można wskazać na dwa skrajne stanowiska dotyczące realizacji celów:

- $\quad \mathrm{z}$ jednej strony przypisuje się tej inicjatywie cele ekonomiczne ograniczone do realizacji wąskich projektów infrastrukturalnych;

- $\quad \mathrm{z}$ drugiej zaś strony akcentuje się dalekosiężne cele polityczne ${ }^{184}$.

Tym samym sprzeczność stanowisk implikuje trudność $\mathrm{w}$ jednoznacznym określeniu postulatów do realizacji. Na oficjalnej stronie Inicjatywy można przeczytać, że jest to „,nieformalna platforma prezydencka, która zapewnia silnie i trwałe wsparcie polityczne

\footnotetext{
${ }^{183}$ Polityka migracyjna Polski, projekt dokumentu z dnia 10.06.2019, za: https://interwencjaprawna.pl/wpcontent/uploads/2019/06/Polityka-migracyjna-Polski-wersja-ostateczna.pdf (10.04.2020).

${ }^{184}$ P. Kowal, A. Orzelska - Stączek, Inicjatywa Trójmorza: geneza, cele i funkcjonowania, Instytut Studiów Politycznych Polskiej Akademii Nauk, s. 75-90.
} 
w celu wspierania skuteczniejszej współpracy międzyrządowej oraz podmiotów

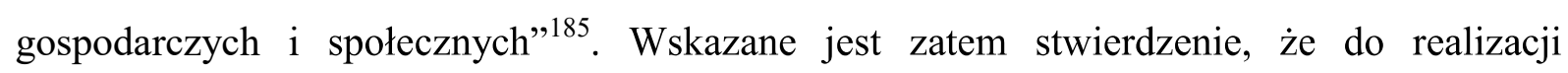
projektów gospodarczych potrzebne jest zaplecze w postaci siły roboczej. Biorąc pod uwagę przeprowadzoną w tej części artykułu analizę państwa regionu Trójmorza mogłyby do agendy włączyć tematy związane $\mathrm{z}$ uwarunkowaniami społecznymi takimi jak migracje oraz populacja. Bez podjęcia działań możliwe, że państwa będą narażone na negatywne konsekwencje wynikające ze zmieniającej się struktury populacji. Wspólne działania pozwoliłby na efektywne działanie w obszarze bezpieczeństwa społecznego i ekonomicznego.

\section{Streszczenie:}

$\mathrm{W}$ artykule zaproponowano powiązanie kwestii migracji $\mathrm{z}$ bezpieczeństwem społecznym i ekonomicznym. Problematyka migracji i możliwych implikacji dla bezpieczeństwa dotyczy właściwie wszystkich krajów na świecie. Aby, geograficznie ograniczyć pole badań zdecydowano się scharakteryzować państwa Inicjatywy Trójmorza. Migracje ludności są powiązane ze zmiennymi demograficznymi. Jest to konstatacja, która implikuje następujący wniosek: wymienione kategorie wzajemnie na siebie oddziałują. Zmienne demograficzne oraz migracje powinno się rozpatrywać wspólnie, gdyż tworzą kompleksowy obraz badanej rzeczywistości.

\section{Słowa kluczowe:}

migracje, bezpieczeństwo społeczne, bezpieczeństwo ekonomiczne, Inicjatywa Trójmorza, zmienne demograficzne

\section{Key words:}

migrations, social security, economic security, the Three Seas Initiative, demographic variables

\section{Bibliografia:}

1. Age dependency

ratio

(\% of

workin age population), https://data.worldbank.org/indicator/SP.POP.DPND;

2. Apanowicz J., Metodologia ogólna, Wydawnictwo Bernardinum, Gdynia 2002;

3. Central Statistical Bureau of Latvia, https://data1.csb.gov.lv/pxweb/en/iedz/iedz_migr/IBG010.px/;

4. Foreign citizens residing in Hungary by continents, countries, sex, 1 January (1995), http://www.ksh.hu/docs/eng/xstadat/xstadat_annual/i_wnvn001b.html;

5. Foreigners: Illegal migration, Czech Statistical Office, https://www.czso.cz/csu/cizinci/1-ciz_nelegalni_migrace;

${ }^{185}$ Inicjatywa Trójmorza, za: http://three-seas.eu/qa/ (4.04.2020). 
6. External migration, years, Statistic Estonia, https://www.stat.ee/34286;

7. Foreigners: Number of foreigners, Czech Statistical Office, https://www.czso.cz/csu/cizinci/1-ciz_pocet_cizincu;

8. Hungarian Central Statistical Office, http://www.ksh.hu/docs/eng/xstadat/xstadat_annual/i_wnvn004.html;

9. Inicjatywa Trójmorza: https: //three.si/

10. Kowal P., Orzelska - Stączek A.,, Inicjatywa Trójmorza: geneza, cele $i$ funkcjonowania, Instytut Studiów Politycznych Polskiej Akademii Nauk

11. Ludność. Stan i struktura oraz ruch naturalny w przekroju terytorialnym w 2018 r. Stan $w$ dniu 31 XII, Główny Urząd Statystyczny, https://stat.gov.pl/obszarytematyczne/ludnosc/ludnosc/ludnosc-stan-i-struktura-oraz-ruch-naturalny-wprzekroju-terytorialnym-w-2018-r-stan-w-dniu-31-xii,6,25.html

12. Migration changes, Slovenia, 2018, Republic of Slovenia Statistical Office, https://www.stat.si/StatWeb/en/News/Index/8217;

13. Migration overview, Statistics Austria, http://www.statistik.at/web_en/statistics/PeopleSociety/population/migration/migratio n_total/index.html;

14. Misiuk A., O tożsamości nauk o bezpieczeństwie, Historia i Polityka Nr 23(30)/2018.

15. National statistics in 2018, Republic of Slovenia Statistical Office, https://www.stat.si/StatWeb/File/DocSysFile/10615/LPSR-2018-ang.pdf;

16. OECD (2018), International Migration Outlook 2018, OECD Publishing, Paris, https://doi.org/10.1787/migr_outlook-2018-en

17. Official Statistic Portal, https://osp.stat.gov.lt/statistiniu-rodikliu-analize?theme=all\#/;

18. Polityka migracyjna Polski, projekt dokumentu $\mathrm{z}$ dnia 10.06.2019 https://interwencjaprawna.pl/wp-content/uploads/2019/06/Polityka-migracyjnaPolski-wersja-ostateczna.pdf

19. Population and demographic processes 2018, National statistical institute, Sofia 2019, https://www.nsi.bg/sites/default/files/files/publications/DMGR2018.pdf;

20. Population Reference Bureau https: //www.prb.org/international/geography/world

21. Press release no 212/29.08.2019, National Institute of Statistics, http://www.insse.ro/cms/sites/default/files/com_presa/com_pdf/poprez_ian2019e.pdf;

22. Sachs J., Nasze wspólne bogactwo. Ekonomia dla przeludnionej planety, Wydawnictwo Naukowe PWN, Warszawa 2009

23. Slovak Republic in Figures 2019, Statistical Office of the Slovak Republic, https://slovak.statistics.sk/;

24. Statistical Yearbook of the Czech Republic - 2019, Czech Statistical Office, https://www.czso.cz/csu/czso/4-population-1gohqz7tfv;

25. Statistical yearbook of Lithuania (edition 2019), Official Statistic Portal, https:/osp.stat.gov.lt/lietuvos-statistikos-metrastis/lsm-2019/gyventojai-ir-socialinestatistika/nuolatiniai-gyventojai;

26. Statistical Yearbook of the Republic of Croatia, Croatian Bureau of Statistic, Zagreb 2018, https://www.dzs.hr/Hrv_Eng/ljetopis/2018/sljh2018.pdf;

27. Stiglitz J., Wizja sprawiedliwej globalizacji, PWN, Warszawa 2007

28. Stokowski F., Demografia, Polskie Wydawnictwo 